\title{
Etiology and antimicrobial susceptibility of udder pathogens from cases of subclinical mastitis in dairy cows in Sweden
}

\author{
Ylva Persson ${ }^{1,2^{*}},{ }$, Ann-Kristin J Nyman ${ }^{1+}$ and Ulrika Grönlund-Andersson ${ }^{1+}$
}

\begin{abstract}
Background: A nationwide survey on the microbial etiology of cases of subclinical mastitis in dairy cows was carried out on dairy farms in Sweden. The aim was to investigate the microbial panorama and the occurrence of antimicrobial resistance. Moreover, differences between newly infected cows and chronically infected cows were investigated.

Methods: In total, 583 quarter milk samples were collected from 583 dairy cows at 226 dairy farms from February 2008 to February 2009. The quarter milk samples were bacteriological investigated and scored using the California Mastitis Test. Staphylococci were tested for betalactamase production and presence of resistance was evaluated in all specific udder pathogens. Differences between newly infected cows and chronically infected cows were statistically investigated using logistic regression analysis.

Results: The most common isolates of 590 bacteriological diagnoses were Staphylococcus (S) aureus (19\%) and coagulase-negative staphylococci (CNS; 16\%) followed by Streptococcus (Str) dysgalactiae (9\%), Str. uberis (8\%), Escherichia (E.) coli (2.9\%), and Streptococcus spp. (1.9\%). Samples with no growth or contamination constituted 22\% and $18 \%$ of the diagnoses, respectively. The distribution of the most commonly isolated bacteria considering only bacteriological positive samples were: S. aureus - 31\%, CNS - 27\%, Str. dysgalactiae - 15\%, Str. uberis - 14\%, E. coli 4.8\%, and Streptococcus spp. - 3.1\%. There was an increased risk of finding S. aureus, Str. uberis or Str. dysgalactiae in milk samples from chronically infected cows compared to findings in milk samples from newly infected cows. Four percent of the S. aureus isolates and 35\% of the CNS isolates were resistant to penicillin G. Overall, resistance to other antimicrobials than penicillin $G$ was uncommon.
\end{abstract}

Conclusions: Staphylococcus aureus and CNS were the most frequently isolated pathogens and resistance to antimicrobials was rare.

\section{Background}

Mastitis is the most prevalent and most costly production disease in dairy herds worldwide [1]. The most frequently isolated micro-organisms are staphylococci, streptococci and coliforms, but other micro-organisms may infect the udder. The panorama of udder pathogens varies between countries and also between types of mastitis, e.g. clinical and subclinical.

\footnotetext{
* Correspondence: ylva.persson@sva.se

† Contributed equally

'Department of animal health and antimicrobial strategies, National

Veterinary Institute, SE-751 89 Uppsala, Sweden

Full list of author information is available at the end of the article
}

National surveys on microbial etiology of subclinical bovine mastitis have, until now, not been performed in Sweden. However, a nationwide survey on the microbial etiology of clinical mastitis was performed in 2002-2003 and revealed that Staphylococcus (S.) aureus, Escherichia (E.) coli and streptococci were the dominating findings [2]. There are no reliable data on the incidence of subclinical mastitis in Sweden, but the annual geometric average bulk-milk somatic cell counts (BMSCC), which reflects cases of subclinical mastitis in a herd, was 190 000 cells/ml in 2009 (Swedish Dairy Association, 2009). This indicates that the incidence should be rather low since a high incidence would be reflected by higher national BMSCC. Subclinical mastitis can cause

\section{() Biomed Central}


substantial economic loss due to reduced milk production [3] and dairy plant fines because of high BMSCC. Moreover, cows with subclinical mastitis should be considered as a risk for spread of mastitis pathogens within and between herds and are as such of national concern.

Antimicrobials are an important tool in mastitis control programs. Therefore, surveillance of antimicrobial resistance is important to ensure optimal results of antimicrobial use and minimize the risk for selection and spread of antimicrobial resistance. The Swedish recommended antimicrobial treatment for subclinical mastitis is selected intramammary treatment at drying off (new Swedish policy for antibiotic treatment of cattle, unpublished 2011). Antibiotic treatment during lactation is not recommended according to Swedish policy in cases of subclinical mastitis. Moreover, in Sweden use of antimicrobials is on prescription only. The most recent nationwide survey of antimicrobial susceptibility was published in 2009, where the overall resistance was low [4]. This study was on clinical mastitis and a survey on antimicrobial susceptibility among pathogens causing subclinical mastitis was therefore important.

The purpose of this survey was to investigate the microbial panorama associated with subclinical mastitis and to determine antimicrobial susceptibility of udder pathogens in a random selection of dairy herds in Sweden. Moreover, a specific aim of the study was also to investigate differences between newly infected cows and chronically infected cows.

\section{Methods Study Design}

A target sample size of 1000 cows in both category (newly infected or chronically infected) was set and that number should be reached during one year excluding the summer months (June, July and August). The number of cows and the number of bovine practitioners in each Swedish county was accessible and a county proportion in relation to the total number of cows in Sweden was calculated. Then, the number of cows per month to be included in the study was calculated for each veterinarian, based on the goal of 1000 cows.

On the sampling occasion the veterinarian also registered data about the cow and the herd by using a specified questionnaire; breed of the cow, lactation number, date of latest calving, milk yield at latest monthly milk recording and presence of teat lesions were recorded as were number of cows in the herd and if automatic milking systems was used.

\section{Animals}

The two different categories of subclinical, i.e. newly infected cows (category 1) and cows chronically infected (category 2) were defined according to history in somatic cell count (SCC). Cows with a SCC $\geq 200000$ cells $/ \mathrm{ml}$ at the latest monthly test milking and with a $\mathrm{SCC}<100000$ cells $/ \mathrm{ml}$ at the previous test milking were classified as category 1 cows. Cows with a SCC>300 000 cells $/ \mathrm{ml}$ at both the latest and previous monthly test milking were classified as category 2 cows. In addition, other inclusion criteria for both categories were no clinical signs of mastitis i.e. no fever, no inappetence, normal milk appearance and no consistency changes in the udder [5].

One cow from each category was sampled per herd. The same herd was allowed to be included several times but not the same cows. Milk samples were taken by veterinarians when they visited the farm for another reason. If there were more than one cow that fitted the criteria for a category, the veterinarian had been given a randomly picked digit (0 to 9 ) on the submission form. If one of the cows that fitted in the study had that digit on her identity tags, she was sampled. If none of the cows that fitted the criteria had that digit, the veterinarian was asked to sample the cow that had the nearest higher digit compared to the one given on the submission form.

\section{Milk Samples}

Udder quarter milk from the two selected cows, one category 1 and one category 2, were analyzed by California Mastitis Test (CMT) [6] by the veterinarian. The CMT-reaction was graded from 1 to 5 . The scores are ranked according to an increase in viscosity, where the highest viscosity (CMT 5) is more or less correlated to the highest SCC. If the udder quarter milk had CMT $\geq$ 3 , an aseptic milk sample was taken. If more than one quarter had CMT $\geq 3$ they were all sampled and then one of the samples was randomly picked at the laboratory and included in the study.

\section{Bacteriological Analyses}

Milk samples were sent by post to the National Veterinary Institute, Uppsala, Sweden. Milk samples (10 $\mu \mathrm{l})$ were cultured on blood ( $5 \%$ bovine blood) agar plates, incubated at $37^{\circ} \mathrm{C}$ for $16-24 \mathrm{~h}$. Growth on the plates was confirmed by additional laboratory tests in accordance with the routines at the laboratory. S. aureus was identified by means of typical colony morphology, $\alpha$ and $\beta$-hemolysis, or by coagulase reaction (coagulasepositive) when typical hemolysis zones were not present. Coagulase-negative staphylococci were identified by typical colony morphology and coagulase reaction, but were not further characterized for this paper. Streptococci were determined by colony morphology and CAMP-reaction, and 12 biochemical reactions (hippurate, aesculine, salicine, sorbitol, mannitol, raffinose, lactose, saccharose, inuline, trehalose, starch and glycerine) 
were used for typing to the species level. Enterococci were confirmed by Gram-staining and growth of typical colonies on SlaBa-plates (Slanetz \&Bartley Medium, Oxoid Ltd., Basingstoke, England). Gram-negative bacteria with typical colony morphology, and positive for $\mathrm{p}$ nitrophenyl-b-D-glucupyranosiduronic acid (PGUA) and indole were considered as E. coli. For other Gram-negative bacteria, oxidase reaction and API $20 \mathrm{E}$ or API 20 NE (BioMérieux, Craponne, France) was used. Bacillus spp. was confirmed by colony morphology and Gramstaining. A milk sample was classified as positive if at least one colony-forming unit (CFU) of $S$. aureus or Streptococcus (Str.) agalactiae was isolated. For other agents, the presence of at least three CFUs was needed for positive classification.

Samples were classified as contaminated if three or more bacterial types were isolated from one milk sample and growth of a major udder pathogen was not identified. If growth of a major udder pathogen was found in combination with contaminating species and if the CMT was high, the sample would be diagnosed as positive for growth of the major udder pathogen. Staphylococcus aureus, CNS, Str. uberis, Str. dysgalactiae, Str. agalactiae, E. coli and Klebsiella spp. were selected for susceptibility testing.

\section{Susceptibility Testing}

Isolates were tested for antimicrobial susceptibility by determination of minimum inhibitory concentration (MIC) using a microdilution method. Testing was performed according to recommendations from the Clinical and Laboratory Standards Institute [7] using VetMIC panels (National Veterinary Institute, Uppsala, Sweden) and cation adjusted Mueller-Hinton broth (Becton Dickinson, Cockeysville, USA). Antimicrobials and range of concentrations tested are given in Tables 1, 2 and 3. For testing of oxacillin susceptibility in staphylococci, $2 \%$ $\mathrm{NaCl}$ was added to the broth. Quality control strains, $S$. aureus ATCC 29213, S. aureus ATCC 25923 and E. coli ATCC 25922, tested in parallel with each batch of isolates, were on all occasions within acceptable ranges. All isolates of staphylococci were in addition examined for $\beta$-lactamase production by the "clover-leaf" method as described by Bryan and Godfrey [8]. Staphylococci with MIC for oxacillin $>1 \mathrm{mg} / \mathrm{l}$ were examined for presence of the mecA-gene by PCR according to Smyth and others [9].

Isolates were classified as susceptible or resistant based on species-specific epidemiological cut-off values issued by European Committee on Antimicrobial Susceptibility Testing (EUCAST) http://www.eucast.org. For staphylococci, the EUCAST cut-off value for clindamycin $(>0.25 \mathrm{mg} / \mathrm{l})$ and trimethoprim $(>2 \mathrm{mg} / \mathrm{l})$ would have split the distribution of MICs an inappropriate way. For the same reason, a higher cut-off value $(>0.06$ $\mathrm{mg} / \mathrm{l})$ for ciprofloxacin than recommended by EUCAST $(>0.03 \mathrm{mg} / \mathrm{l})$ was used for E. coli. Classification of staphylococci as resistant to penicillin or oxacillin was based on production of $\beta$-lactamase and presence of $m e c A$ gene respectively. Isolates were not classified as susceptible or resistant when cut-off values from EUCAST were not available.

\section{Statistical Analyses}

Associations between the dependent variable, being a newly infected or chronically infected cow, and each of the independent factors; days in milk (DIM), breed (Swedish Red (SR), Swedish Holstein (SH) or other breed or crossbred), parity and bacteriological findings were investigated using multivariable logistic regression analysis. Herd was not included as a random factor due to too few observations per herd. However, the "cluster" command in Stata (Stata Corp., 2009; Stata Statistical Software: Release 11.1; College Station, TX, USA: StataCorp LP) was used making the standard errors allow for intragroup correlation. Before bacteriological diagnosis was included in the multivariable logistic regression analysis it was amalgamated into eight categories due to few findings of certain bacteria. The eight categories were: no bacterial finding, S. aureus, CNS, Str. uberis, Str. dysgalactiae, E. coli, other bacteria, and contaminated samples. Days in milk was centred (DIM - mean DIM) and squared to get a linear relationship with the outcome on the logit scale.

\section{Results \\ Descriptive Data}

In total, 583 cows, from 226 herds ( 2 - 13 cows/herd), fulfilling the selection criteria (CMT $\geq 3$, and being a cow of category 1 or 2) contributed with 583 quarter milk samples. The participating herd distribution was proportionally equal to the distribution of dairy herds in Sweden (Table 4). The arithmetic mean herd size of these herds was 92 cows (50\% central range (CR): 45 117 cows, $\mathrm{n}=223)$ and the majority of farms $(83 \%, \mathrm{n}=$ 222) had conventional milking systems (parlor or tiestall systems) while $17 \%$ had robotic milking or a combination of robotic milking and conventional milking on the farm. A total of 103 veterinarians participated in the study visiting on average 4 (range 1-11) farms each.

The cows were mainly of the $\mathrm{SH}(53 \%, \mathrm{n}=571)$ or the SR (42\%) breed, the rest were cross-breeds or of other breeds. Cows were of parity 1-9 $(n=579) ; 32 \%$ first parity cows, $25 \%$ second parity cows, $21 \%$ third parity cows and $21 \%$ of parity four or higher. Mean daily milk yield (on the test-day closest before sampling) were $32 \mathrm{~kg}$ of milk (50\% CR: $25-37.5 \mathrm{~kg}$ of milk) and the cows were sampled on average on day 176 DIM (50\% CR: 92 - 244 DIM). 
Table 1 Resistance and distribution of MIC for Staphylococcus aureus $(n=109)$ and coagulase negative staphylococci (CNS; $\mathbf{n}=\mathbf{9 5}$ )

\begin{tabular}{|c|c|c|c|c|c|c|c|c|c|c|c|c|c|c|}
\hline \multirow[b]{2}{*}{ Substance } & \multirow[b]{2}{*}{ Species } & \multirow[b]{2}{*}{$\begin{array}{c}\text { Resistance } \\
\text { (\%) }\end{array}$} & \multicolumn{12}{|c|}{ Distribution (\%) of $\mathrm{MICs}{ }^{\text {a }}(\mathrm{mg} / \mathrm{l})$} \\
\hline & & & $\leq 0.03$ & 0.06 & 0.12 & 0.25 & 0.5 & 1 & 2 & 4 & 8 & 16 & 32 & $>64$ \\
\hline \multirow[t]{2}{*}{ Cephalothin } & S. aureus & 0 & & 0.9 & 46.7 & 45.0 & 6.4 & & & & & & & \\
\hline & CNS & - & & 4.2 & 25.3 & 53.7 & 9.5 & 6.3 & 4.2 & & & & & \\
\hline \multirow[t]{2}{*}{ Chloramphenicol } & S. aureus & 0 & & & & & & & 0.9 & 21.1 & 75.0 & 3.0 & & \\
\hline & CNS & 0 & & & & & & 1.1 & 6.3 & 71.6 & 21.2 & & & \\
\hline \multirow[t]{2}{*}{ Ciprofloxacin } & S. aureus & 0 & & 1.8 & 17.4 & 55.0 & 24.8 & 0.9 & & & & & & \\
\hline & CNS & 0 & & 7.4 & 48.4 & 37.9 & 6.3 & & & & & & & \\
\hline \multirow[t]{2}{*}{ Clindamycin } & S. aureus & - & & & & 91.7 & 8.3 & & & & & & & \\
\hline & CNS & - & & & & 80.9 & 15.8 & 2.1 & & & & & & 1.1 \\
\hline \multirow[t]{2}{*}{ Erythromycin } & S. aureus & 0 & & & & 12.8 & 79.8 & 7.3 & & & & & & \\
\hline & CNS & 2 & & & & 30.5 & 60.0 & 7.4 & 0 & & & 1.1 & & 1.1 \\
\hline \multirow[t]{2}{*}{ Gentamicin } & S. aureus & 0 & & & & & 67.0 & 31.2 & 1.8 & & & & & \\
\hline & CNS & 1 & & & & & 98.9 & 1.1 & & & & & & \\
\hline \multirow[t]{2}{*}{ Kanamycin } & S. aureus & 4 & & & & 0.9 & 0.9 & 12.8 & 60.6 & 21.1 & & 2.8 & 0.9 & \\
\hline & CNS & - & & & & 11.6 & 42.1 & 38.9 & 5.3 & 2.1 & & & & \\
\hline \multirow[t]{2}{*}{ Oxacillin } & S. aureus & 0 & & & & 41.2 & 47.7 & 10.1 & 0.9 & & & & & \\
\hline & CNS & 10 & & & 0.9 & 40.0 & 43.2 & 5.3 & 8.4 & 2.1 & & & & \\
\hline \multirow[t]{2}{*}{ Penicillin ${ }^{c}$} & S. aureus & 4 & 35.8 & 43.1 & 17.4 & & & 0.9 & 1.8 & & 0.9 & & & \\
\hline & CNS & 37 & 36.8 & 13.7 & 13.7 & 10.5 & 13.7 & 8.4 & 1.1 & 1.2 & 1.1 & & & \\
\hline \multirow[t]{2}{*}{ Tetracycline } & S. aureus & 3 & & & & & 95.4 & 1.8 & 2.8 & & & & & \\
\hline & CNS & 1 & & & & & 87.4 & 11.6 & & & & & & 1.1 \\
\hline \multirow[t]{2}{*}{ Trimethoprim } & S. aureus & - & & & & & 3.7 & 12.8 & 61.5 & 18.3 & 3.7 & & & \\
\hline & CNS & - & & & & & 9.5 & 25.3 & 31.6 & 10.5 & 12.6 & 8.4 & 1.1 & 1.1 \\
\hline
\end{tabular}

\section{Distribution of Udder Pathogens}

At least one microbial species supposedly associated with mastitis was isolated from $350(60 \%)$ of the 583 quarter milk samples. From the majority of those quarter milk samples one species was isolated (343 of the samples (99\%)). In total, 590 microbial diagnoses were obtained from 583 quarter milk samples. The distribution of microbial diagnoses is shown in Table 5. The distribution of the most commonly isolated bacteria considering only bacteriological positive samples were: S. aureus - 31\%, CNS - 27\%, Str. dysgalactiae - 15\%, Str. uberis - 14\%, E. coli $-4.8 \%$, and Str. spp. - 3.1\%.

\section{Newly infected versus Chronic cases}

The result of the multivariable analysis is presented in Table 6. The odds of finding S. aureus, Str. dysgalactiae or Str. uberis in milk samples was 2, 2.8, and 2.3 times higher, respectively, in milk samples from chronically infected cows compared to newly infected cows. Moreover, there was an association between being a chronically infected cow and time of sampling in relation to calving $(\mathrm{P}<0.001)$. At an increased DIM at sampling from median DIM (157 DIM) to third quartile (242.5 DIM) the odds was 1.6 that the cow sampled was a chronically infected cow compared to being a newly infected cow. No other significant differences were seen between the two groups of cows.

\section{Antimicrobial Susceptibility Testing}

Of the $S$. aureus resistant to penicillin through $\beta$-lactamase production (3.7\%), all had MICs for penicillin $>0.5$ $\mathrm{mg} / \mathrm{l}$. Two of these $S$. aureus were isolated from cows in the same herd. Distributions of MICs for the different substances are shown in Table 1.

Of the $35 \mathrm{CNS}$ isolates resistant to penicillin through $\beta$-lactamase production $31 \mathrm{had}$ MICs $>0.12 \mathrm{mg} / \mathrm{l}$ for penicillin. The prevalence of $\beta$-lactamase producing CNS was equal between newly and chronically infected cows. Four CNS positive for $\beta$-lactamase production had MICs of $0.12 \mathrm{mg} / \mathrm{l}$ or lower for penicillin. Three 
Table 2 Resistance and distribution of MIC for Streptococcus dysgalactiae $(\mathrm{n}=50)$ and Streptococcus uberis $(\mathrm{n}=50$ )

\begin{tabular}{|c|c|c|c|c|c|c|c|c|c|c|c|c|c|c|c|}
\hline \multirow[b]{2}{*}{ Substance } & \multirow[b]{2}{*}{ Species } & \multirow[b]{2}{*}{$\begin{array}{c}\text { Resistance } \\
\text { (\%) }\end{array}$} & \multicolumn{13}{|c|}{ Distribution (\%) of $\mathrm{MICs}{ }^{\text {a }}(\mathrm{mg} / \mathrm{l})$} \\
\hline & & & $\leq 0.03$ & 0.06 & 0.12 & 0.25 & 0.5 & 1 & 2 & 4 & 8 & 16 & 32 & 64 & $>64$ \\
\hline \multirow[t]{2}{*}{ Cephalothin } & S. dysg. & - & & 2.0 & 82.0 & 16.0 & & & & & & & & & \\
\hline & S. uberis & - & & 4.0 & 50.0 & 42.0 & 2.0 & 2.0 & & & & & & & \\
\hline \multirow[t]{2}{*}{ Chloramphenicol } & S. dysg. & - & & & & & & 6.0 & 28.0 & 66.0 & & & & & \\
\hline & S. uberis & - & & & & & & & 36.0 & 62.0 & 2.0 & & & & \\
\hline \multirow[t]{2}{*}{ Ciprofloxacin } & S. dysg. & - & & & & 10.0 & 48.0 & 40.0 & 2.0 & & & & & & \\
\hline & S. uberis & - & & & & 4.0 & 54.0 & 40.0 & 2.0 & & & & & & \\
\hline \multirow[t]{2}{*}{ Clindamycin } & S. dysg. & - & & & & 100 & & & & & & & & & \\
\hline & S. uberis & - & & & & 100 & & & & & & & & & \\
\hline \multirow[t]{2}{*}{ Erythromycin } & S. dysg. & - & & & & 100 & & & & & & & & & \\
\hline & S. uberis & - & & & & 100 & & & & & & & & & \\
\hline \multirow[t]{2}{*}{ Gentamicin } & S. dysg. & - & & & & & & 12.0 & 24.0 & 62.0 & 2.0 & & & & \\
\hline & S. uberis & - & & & & & & & 20.0 & 20.0 & 28.0 & 30.0 & 2.0 & & \\
\hline \multirow[t]{2}{*}{ Kanamycin } & S. dysg. & - & & & & & & 2.0 & 4.0 & 4.0 & 4.0 & 12.0 & 68.0 & 6.0 & \\
\hline & S. uberis & - & & & & & & & & 6.0 & 6.0 & 18.0 & 20.0 & 50.0 & \\
\hline \multirow[t]{2}{*}{ Penicillin ${ }^{c}$} & S. dysg. & - & 72.0 & 18.0 & 10.0 & & & & & & & & & & \\
\hline & S. uberis & - & 46.0 & 34.0 & 14.0 & 6.0 & & & & & & & & & \\
\hline \multirow[t]{2}{*}{ Tetracycline } & S. dysg. & - & & & & & 4.0 & & 14.0 & 70.0 & 8.0 & & 2.0 & 2.0 & \\
\hline & S. uberis & - & & & & & 86.0 & 2.0 & 4.0 & 4.0 & & & 4.0 & & \\
\hline \multirow[t]{2}{*}{ Trimethoprim } & S. dysg. & - & & & & & 14.0 & 36.0 & 46.0 & 4.0 & & & & & \\
\hline & S. uberis & - & & & & & & 20.0 & 64.0 & 14.0 & 2.0 & & & & \\
\hline
\end{tabular}

${ }^{a}$ Thin vertical lines denote range of dilutions tested for each substance. MICs above the range are given as the concentration closest to the range. MICs equal to or lower than the lowest concentration tested are given as the lowest tested concentration. Bold vertical lines indicate EUCAST epidemiological cut-off values. When no cut-off value is available isolates are not classified as susceptible or resistant.

Table 3 Resistance and distribution of MIC for Escherichia coli $(\mathbf{n}=17)$

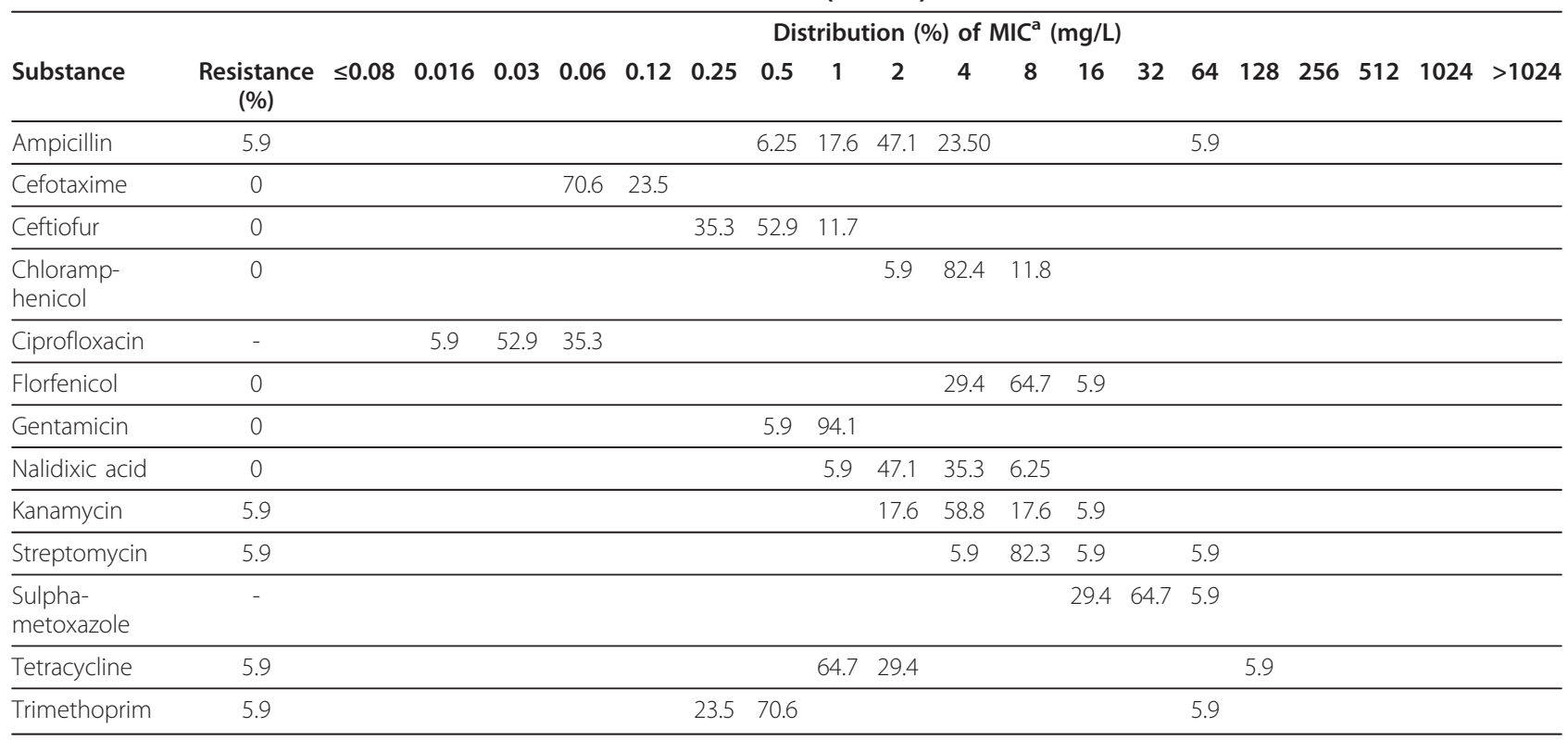

${ }^{a}$ Thin vertical lines denote range of dilutions tested for each substance. MICs above the range are given as the concentration closest to the range. MICs equal to or lower than the lowest concentration tested are given as the lowest tested concentration. Bold vertical lines indicate EUCAST epidemiological cut-off values with exception of ciprofloxacin. When no cut-off value is available isolates are not classified as susceptible or resistant. 
Table 4 Distribution of sampled herds per county/ies and overall distribution of dairy herds per county/ies in Sweden

\begin{tabular}{lrr}
\hline County & Number of sampled herds & Number of dairy herds (SJV; 2008) \\
\hline Skåne & $23(9 \%)$ & $657(9 \%)$ \\
Halland & $20(9 \%)$ & $413(6 \%)$ \\
Kalmar, Gotland, Blekinge and Kronoberg & $33(14 \%)$ & $1331(19 \%)$ \\
Östergötland, Jönköping, and parts of Västra Götaland county & $66(28 \%)$ & $2068(29 \%)$ \\
Västra Götaland & $8(3 \%)$ & $294(4 \%)$ \\
Stockholm, Uppsala, Södermanland, Värmland, Örebro, & $71(31 \%)$ & $1803(25 \%)$ \\
Västmanland, Dalarna, Gävleborg, Västernorrland, and Jämtland & & $530(7 \%)$ \\
Västerbotten and Norrbotten & $11(5 \%)$ & $\mathbf{7 0 9 6}$ \\
\hline Total number of herds & $\mathbf{2 3 2}$ \\
\hline
\end{tabular}

CNS isolates had MICs of $0.25,0.25$ and $1 \mathrm{mg} / \mathrm{l}$ for penicillin, respectively, although they were negative for $\beta$-lactamase production. Two (2.1\%) isolates tested were resistant to one or more antimicrobial; one isolate was resistant to penicillin and erythromycin and the other was resistant penicillin, erythromycin and tetracycline. One penicillin susceptible CNS isolate was resistant to gentamicin. Ten CNS isolates with $\mathrm{MIC}>1 \mathrm{mg} / \mathrm{l}$ for oxacillin were tested for presence of the mecA-gene by PCR but none were positive. Distributions of MICs for the different substances are shown in Table 1.

The results for streptococci are difficult to evaluate since EUCAST cut-off values are lacking for the species tested. Bimodal distributions of MICs for tetracycline for both Str. dysgalactiae and Str. uberis indicate acquired resistance in some isolates (Table 2).

Most E. coli were susceptible to antimicrobials tested with exception of two isolates; one was resistant to trimethoprim and the other was resistant to ampicillin, streptomycin and tetracycline (Table 3). Resistance to cefotaxime did not occur in E. coli and Klebsiella spp. indicating that none of the isolates produced extended spectrum betalactamases (ESBL).

\section{Discussion}

This is the first national survey of subclinical mastitis in dairy cows in Sweden. The cows were sampled under strict inclusion criteria and originated from all parts of the country, why the isolates should represent a random sample of pathogens causing subclinical mastitis in Swedish dairy cows.

In this study, the most frequently isolated bacterial species was $S$. aureus followed by CNS. In most studies, staphylococci and streptococci are the most common findings in subclinical mastitis [10-16]. In a Finnish study, CNS was the most commonly isolated bacterial group (49.6\% of the positive findings), followed by Corynebacterium bovis (34.4\%) and S. aureus (10.2\%) [17]. Corynebacterium bovis was uncommon in this study and is seldom recognized as a mastitis pathogen in Sweden.

One fifth of the samples submitted for culturing appeared to be negative. A reason for this may be that

Table 5 Distribution of bacteriological diagnoses from quarter milk samples from cows newly or chronically infected with subclinical mastitis

\begin{tabular}{|c|c|c|c|}
\hline Diagnosis & Newly infected cows (n, \%) & Chronically infected cows (n, \%) & Total \\
\hline Staphylococcus aureus & $44(15 \%)$ & $66(22 \%)$ & $110(18.6 \%)$ \\
\hline Coagulase-negative staphylococci & $51(18 \%)$ & $46(15 \%)$ & $97(16.4 \%)$ \\
\hline Streptococcus dysgalactiae & $21(7.3 \%)$ & $33(11 \%)$ & $54(9.2 \%)$ \\
\hline Streptococcus uberis & $18(6.4 \%)$ & $31(10 \%)$ & $49(8.3 \%)$ \\
\hline Streptococcus agalactiae & 0 & $1(0.3 \%)$ & $1(0.2 \%)$ \\
\hline Other streptococci & $4(1.4 \%)$ & $7(2.3 \%)$ & $11(1.9 \%)$ \\
\hline Enterococci & $1(0.3 \%)$ & $4(1.3 \%)$ & $5(0.8 \%)$ \\
\hline Arcanobacterium pyogenes & $1(0.3 \%)$ & $1(0.3 \%)$ & $2(0.3 \%)$ \\
\hline Escherichia coli & $7(2.5 \%)$ & $10(3.3 \%)$ & $17(2.9 \%)$ \\
\hline Klebsiella spp. & $3(1.1 \%)$ & $2(0.7 \%)$ & $5(0.8 \%)$ \\
\hline Other coliform bacteria & $2(0.7 \%)$ & $1(0.3 \%)$ & $3(0.5 \%)$ \\
\hline Other bacteria & $2(0.7 \%)$ & $1(0.3 \%)$ & $3(0.5 \%)$ \\
\hline Contaminated & $60(21 \%)$ & $45(15 \%)$ & $105(17.8 \%)$ \\
\hline No growth & $72(25 \%)$ & $56(19 \%)$ & $128(21.7 \%)$ \\
\hline Total & 286 & 304 & 590 \\
\hline
\end{tabular}


Table 6 Results from the multivariable logistic regression analysis of factors associated with being a cow newly or chronically infected with subclinical mastitis in $\mathbf{5 7 8}$ dairy cows from 262 Swedish dairy herds ( $r 2=00.6)$

\begin{tabular}{|c|c|c|c|c|c|}
\hline Variable & $\beta$ & $\mathrm{SE}(\boldsymbol{\beta})$ & $\mathrm{OR}^{\mathrm{a}}$ & $\begin{array}{c}95 \% \mathrm{Cl}^{\mathrm{b}} \\
\left(\mathrm{OR}^{\mathrm{a}}\right)\end{array}$ & $\begin{array}{c}P- \\
\text { value }\end{array}$ \\
\hline Intercept & -0.17 & 0.17 & - & - & - \\
\hline \multicolumn{6}{|l|}{ Bacteriological finding } \\
\hline 1: No bacterial finding & Ref. $^{c}$ & - & - & - & - \\
\hline $\begin{array}{l}\text { 2: Staphylococcus } \\
\text { aureus }\end{array}$ & 0.71 & 0.27 & 2.03 & $\begin{array}{l}(1.17 ; \\
3.52)\end{array}$ & 0.01 \\
\hline 3: Coagulase-negative & 0.17 & 0.27 & 1.18 & $\begin{array}{l}(0.68 ; \\
2.06)\end{array}$ & 0.55 \\
\hline \multicolumn{6}{|l|}{ staphylococci } \\
\hline 4: Streptococcus & 0.82 & 0.33 & 2.27 & $\begin{array}{l}(1.12 ; \\
4.60)\end{array}$ & 0.02 \\
\hline \multicolumn{6}{|l|}{ dysgalactiae } \\
\hline 5: Streptococcus uberis & 1.02 & 0.35 & 2.78 & $\begin{array}{l}(1.38 ; \\
5.62)\end{array}$ & 0.004 \\
\hline 6: Escherichia coli & 0.67 & 0.58 & 1.95 & $\begin{array}{l}(0.68, \\
5.62)\end{array}$ & 0.21 \\
\hline 7: Other bacteria & 0.63 & 0.38 & 1.87 & $\begin{array}{l}(0.88 ; \\
4.00)\end{array}$ & 0.11 \\
\hline 8: Contaminated & 0.002 & 0.27 & 1.00 & $\begin{array}{l}(0.58 ; \\
1.72)\end{array}$ & 0.99 \\
\hline $\begin{array}{l}\text { Days in milk } \\
\text { (centered) }\end{array}$ & 0.005 & 0.0009 & n.a. ${ }^{d}$ & n.a. $^{d}$ & n.a. ${ }^{d}$ \\
\hline Days in milk (squared) & -0.00001 & 0.000004 & $1.56^{\mathrm{e}}$ & $1.33 ; 1.83$ & 0.006 \\
\hline
\end{tabular}

${ }^{\mathrm{a} O R}=$ odds ratio

${ }^{\mathrm{b}} \mathrm{Cl}=$ confidence interval

${ }^{\mathrm{c}}$ Ref. = reference category

${ }^{d}$ n.a. = not applicable

eOdds ratio is calculated for an interquartile increase from the mean in days in milk (85.5 DIM) in both DIM (centered) and DIM (squared)

the number of colony forming units in milk is below the detection limit of the assay. Another reason for the negative results may be spontaneous bacteriological recovery. However, a single milk sample has been shown to have a rather low sensitivity in finding infecting bacteria [18], and if this study should be repeated the proportion of negative samples could be reduced if each cow was sampled repeatedly within a few days.

The reasons for the pre-dominance of $S$. aureus and CNS in subclinical mastitis in Sweden are not clear, but housing system and herd size are factors that might be of importance. Tie stalls are still common in Sweden and Ericsson Unnerstad et al. [2] reported an association between tie stalls and $S$. aureus in their study. Historically in Sweden, S. aureus has been the most predominant bacteria causing both clinical and subclinical mastitis. Hence, the result in this study was expected. Moreover, Str. agalactiae, a common finding in many other studies was very rare in this study with less than $1 \%$ of the positive findings. The reason for this could be awareness among Swedish veterinarians regarding this bacteria and effective treatment and eradication schemes.

We also found that S. aureus, Str. dysgalactiae and Str. uberis were more prevalent in chronic than in new subclinical cases. The reason for this is not clear, but at least S. aureus and Str. uberis are often involved in chronic cases of mastitis.

$\beta$-lactamase production is the most common resistance mechanism in staphylococci. Overall, such production was most prevalent among CNS isolates, while among $S$. aureus isolates it was lower than expected. Usually cows with $\beta$-lactamase producing $S$. aureus are culled when diagnosed in Swedish dairy herds, and that is the most plausible explanation to the low prevalence. The proportion of $\beta$-lactamase producing CNS isolates (37\%) was similar to those reported from subclinical mastitis or IMI in Finland (32\%), Norway (36\%) and Netherlands (37\%) $[17,19,20]$. Compared to CNS isolated from acute clinical mastitis in Sweden [4], the proportion $\beta$-lactamase producing was higher.

Overall, resistance to other antimicrobials than penicillin $\mathrm{G}$ was rare in all bacteria isolated from cows with subclinical mastitis and was markedly lower than in other studies [11,17]. In addition, no meticillin resistant S. aureus (MRSA) or CNS was found and no ESBL-producing bacteria were detected.

As management and milking systems are continuously changing in the Swedish dairy industry, changes in microbial and resistance patterns might occur in the future. Therefore, studies like the present should be repeated regularly to update the knowledge of trends in the panorama of microorganisms causing subclinical mastitis.

\section{Conclusions}

Staphylococcus aureus and CNS were the most frequently isolated pathogens from cows with subclinical mastitis and resistance to antimicrobials was rare.

\section{Acknowledgements}

Many thanks to the Swedish Board of Agriculture who funded the project, to the practitioners for help with sampling and to the laboratory staff at the National Veterinary Institute for the analyses.

\section{Author details}

${ }^{1}$ Department of animal health and antimicrobial strategies, National Veterinary Institute, SE-751 89 Uppsala, Sweden. ${ }^{2}$ Swedish Dairy Association, c/o National Veterinary Institute, SE-751 89 Uppsala, Sweden.

\section{Authors' contributions}

UG conceived of the study and participated in its coordination and design and helped to draft the manuscript. YP participated in the study,

participated in its coordination and drafted the manuscript. AN performed the statistical analysis and helped to draft the manuscript. All authors read and approved the final manuscript.

\section{Competing interests}

The authors declare that they have no competing interests. 


\section{References}

1. Seegers H, Fourichon C, Beaudeau F: Production effects related to mastitis and mastitis economics in dairy cattle herds. Vet Res 2003, 34(5):475-491.

2. Ericsson Unnerstad H, Lindberg A, Persson Waller K, Ekman T, Artursson $\mathrm{K}$, Nilsson-Ost M, Bengtsson B: Microbial aetiology of acute clinical mastitis and agent-specific risk factors. Vet Microbiol 2009, 137(1-2):90-97.

3. Hagnestam-Nielsen C, Emanuelson U, Berglund B, Strandberg E: Relationship between somatic cell count and milk yield in different stages of lactation. J Dairy Sci 2009, 92(7):3124-3133.

4. Bengtsson B, Unnerstad HE, Ekman T, Artursson K, Nilsson-Ost M, Waller KP: Antimicrobial susceptibility of udder pathogens from cases of acute clinical mastitis in dairy cows. Vet Microbiol 2009, 136(1-2):142-149.

5. IDF: Suggested interpretation of mastitis terminology. International Dairy Federation Bulletine 1999, 3-26.

6. Schalm OW, Carroll EJ, Jain NC: Bovine mastitis. Philadelphia Lea \& Febiger; 1971, 128-157.

7. Performance Standards for Antimicrobial Susceptibility Testing: Sevenenth Informational Supplement. CLSI document M100-S17 Wayne Pennsylvania, USA: Clinical and Laboratory Standards Institute; 2001, 1-153.

8. Bryan LE, Godfrey AJ: Beta-lactam antibiotics: mode of action and bacterial resistance. In Antibiotics in Laboratory Medicine. Edited by: Lorian V. Baltimore, USA: William 1991:648.

9. Smyth RW, Kahlmeter G, Olsson Liljequist B, Hoffman B: Methods for identifying methicillin resistancein Staphylococcus aureus. J Hosp Infect 2001, 48(2):103-107.

10. Gianneechini R, Concha C, Rivero R, Delucci I, Moreno Lopez J: Occurrence of clinical and sub-clinical mastitis in dairy herds in the West Littoral Region in Uruguay. Acta Vet Scand 2002, 43(4):221-230.

11. Kalmus P, Aasmae B, Karssin A, Orro T, Kask K: Udder pathogens and their resistance to antimicrobial agents in dairy cows in Estonia. Acta Vet Scand 2011, 53(1):4.

12. Roesch M, M GD, Scharen W, Schallibaum M, Blum JW: Subclinical mastitis in dairy cows in Swiss organic and conventional production systems. J Dairy Res 2007, 74(1):86-92.

13. Bradley AJ, Leach KA, Breen JE, Green LE, Green MJ: Survey of the incidence and aetiology of mastitis on dairy farms in England and Wales. Vet Rec 2007, 160(8):253-257.

14. Wilson DJ, Gonzalez RN, Das HH: Bovine mastitis pathogens in New York and Pennsylvania: prevalence and effects on somatic cell count and milk production. J Dairy Sci 1997, 80(10):2592-2598.

15. Piepers S, De Meulemeester L, de Kruif A, Opsomer G, Barkema HW, De Vliegher S: Prevalence and distribution of mastitis pathogens in subclinically infected dairy cows in Flanders, Belgium. J Dairy Res 2007, 74(4):478-483.

16. Botrel MA, Haenni M, Morignat E, Sulpice P, Madec JY, Calavas D: Distribution and antimicrobial resistance of clinical and subclinical mastitis pathogens in dairy cows in Rhone-Alpes, France. Foodborne Pathog Dis 2010, 7(5):479-487.

17. Pitkala A, Haveri M, Pyorala S, Myllys V, Honkanen-Buzalski T: Bovine mastitis in Finland 2001-prevalence, distribution of bacteria, and antimicrobial resistance. J Dairy Sci 2004, 87(8):2433-2441.

18. Dohoo IR, Smith J, Andersen S, Kelton DF, Godden S: Diagnosing intramammary infections: evaluation of definitions based on a single milk sample. J Dairy Sci 2011, 94(1):250-261.

19. Osteras O, Solverod L, Reksen O: Milk culture results in a large Norwegian survey-effects of season, parity, days in milk, resistance, and clustering. J Dairy Sci 2006, 89(3):1010-1023.

20. Sampimon OC, Barkema HW, Berends IM, Sol J, Lam TJ: Prevalence and herd-level risk factors for intramammary infection with coagulasenegative staphylococci in Dutch dairy herds. Vet Microbiol 2009, 134(12):37-44.

doi:10.1186/1751-0147-53-36

Cite this article as: Persson et al:: Etiology and antimicrobial susceptibility of udder pathogens from cases of subclinical mastitis in dairy cows in Sweden. Acta Veterinaria Scandinavica 2011 53:36.

\section{Submit your next manuscript to BioMed Central and take full advantage of:}

- Convenient online submission

- Thorough peer review

- No space constraints or color figure charges

- Immediate publication on acceptance

- Inclusion in PubMed, CAS, Scopus and Google Scholar

- Research which is freely available for redistribution

Submit your manuscript at www.biomedcentral.com/submit 